\title{
内頸動脈閉塞試験の合併症
}

-119 例の経験から-

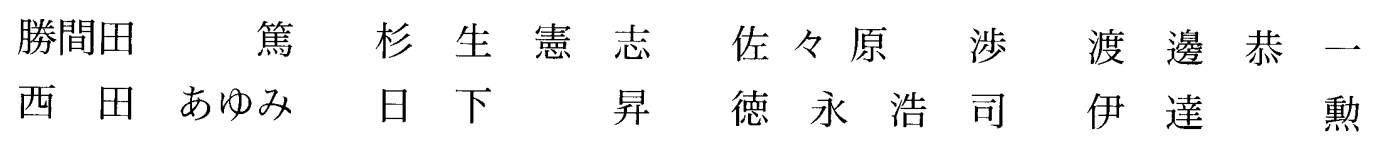

\section{Complication of Temporary Balloon Test Occlusion of the Internal Carotid Artery : Experience in 119 Cases \\ by}

\author{
Atsushi Katsumata, M.D., Kenji Sugiu, M.D., Wataru Sasahara, M.D., Kyoichi Watanabe, M.D., \\ Ayumi Nishida, M.D., Noboru Kusaka, M.D., Koji Tokunaga, M.D., and Isao Date,M.D. \\ from
}

Department of Neurological Surgery, Okayama University Medical School

Currently, temporary balloon test occlusion (BTO) of the internal carotid artery (ICA) has become a well accepted procedure in the preoperative evaluation of patients with large aneurysm or tumor involving the neck or skull base in whom arterial sacrifice or prolonged temporary occlusion is considered. In this paper we review our experience with 119 cases of BTO and evaluate the associated techniques and complications.

BTO of the ICA was accomplished endovascularly using triple-lumen balloon catheter. After ICA occlusion using the balloon, the patient's neurological status was assessed and monitored continuously throughout 30 minutes. When the patient showed neurological changes, BTO was immediately stopped.

Complication related to this procedure occurred in $5(4.2 \%)$ patients. Two $(1.7 \%)$ patients had symptomatic and three $(2.5 \%)$ had asymptomatic complications. One $(0.8 \%)$ of these was a permanent neurological deficit due to ICA dissection caused by the balloon catheter. The other $(0.8 \%)$ was embolic M2 occlusion resulted in transient neurological deficit. There were no death related this procedure.

BTO of the ICA can be performed with an acceptable low complication rate, however, it should be performed by the experienced hand and under strict indication.

(Received December 22, 2003; accepted March 1, 2004)

Key words : internal carotid artery, balloon test occlusion, complication, aneurysm, tumor

Jpn J Neurosurg（Tokyo） $13: 572-577,2004$

\section{はじめに}

巨大脳動脈瘤や，頭蓋底腫瘍等の治療にあたり，脳主 幹動脈の血行遮断が必要となることがある。そのような 場合, 親動脈の一時遮断ないし永久遮断によって生ずる 遠位部の局所的脳虚血に対して，脳組織が耐えられるか
否かを術前にあらかじめ評価しておくことが安全な治療 を行ううえで重要である。頭頸部の主要血管の閉塞試験 は，Matas が用手的圧迫による手技を報告したことに始 まる。その後はバルーンカテーテルを用いた balloon test occlusion（BTO）が主流となり, 現在でも, 主幹動脈の 一時遮断ないし永久閉塞の可否を評価する術前検査とし

岡山大学医学部脳神経外科 $/ \bar{T} 700-8558$ 岡山市鹿田町 2-5-1〔連絡先：杉生憲志〕

Address reprint requests to: Kenji Sugiu, M.D., Department of Neurological Surgery, Okayama University Medical School, 2-5-1 Shikata-cho, Okayama-shi, Okayama 700-8558, Japan 
て重要な検査であり, 広く行われているが(1)45), 本検査 の有用性，合併症等に関する報告は少ない10).

今回われわれは, 当院で行われた頸部および脳主幹動 脈の閉塞試験の中で, 頸部内頸動脈の BTO 施行症例に ついて，特にその合併症に関して検討を行ったので文献 的考察を加え報告する.

\section{対象および方法}

対象は, 1991 年 5 月〜2003 年 5 月までに頸部内頸動 脈の BTO を施行した 119 例（121 血管）について神経 症状の出現の有無, 出現時間, および合併症について検 討した, 年歯は $21 \sim 82$ 歳, 平均 55.5 歳で, 男性 53 例, 女性 66 例であった。これらはすべて病変に対する外科 的治療の中で, 内頸動脈の術中一時遮断あるいは永久的 閉塞が必要となる可能性がある症例であった。

疾患の内訳は, 内頸動脈瘤 58 例 (うち 1 例が両側性), 頭頸部腫瘍 38 例, 内頸動脈狭窄 13 例, 外傷性内頸動脈 海綿静脈洞瘻 (CCF) が 10 例（うち 1 例が両側性）で あった。

BTO は全例局所麻酔下にて行われた。まず，コント ロールの神経学的所見をとった後, 右大腿動脈に $6 \mathrm{~F} の$ シースを留置し通常の診断造影を行った。 その際に患側 頸動脈の用手的圧迫にて対側および椎骨動脈系からの側 副血行の確認を行った。この後に，4,000〜5,000 単位の 全身へパリン化を行い, activated clotting time (ACT) を 2.0〜3.0 倍に保つようにし, 5.5F triple lumen のセレコ ンマルチカテーテル（クリニカル・サプライ社）を内頸 動脈起始部まで誘導, 造影剤で血流を確認しながらバ ルーンを拡張し, 閉塞テストを開始した. 閉塞中のモニ タリングとして神経症状は全例で, さらに症例に応じて stump pressure, 脳波, SEP (somatosensory evoked potential), ABR (auditory brainstem response) を使用し た. 閉塞 20 分後にニカルジピン $1 \sim 2 \mathrm{mg}$ の静脈注入を 行い, 20\%の血压低下, あるいは収縮期血圧が 100 $\mathrm{mmHg}$ 前後となるよう低血圧負荷を加えた。計 30 分間 の閉塞テストを行った後に, バルーン閉塞を解除し終了 した。

判定は，バルーン閉塞中に神経症状が出現したものを 陽性, 出現しなかったものを陰性とし, 症状が出た場合 には直ちにバルーンを解除しテストを終了した。 また， 内頸動脈を永久閉塞する可能性が高い症例については続 けて ${ }^{99 \mathrm{~m}} \mathrm{Tc}-\mathrm{HMPAO}$ を用いてのバルーン閉塞下での SPECT を施行し, 虚血の範囲, 程度を評価した。

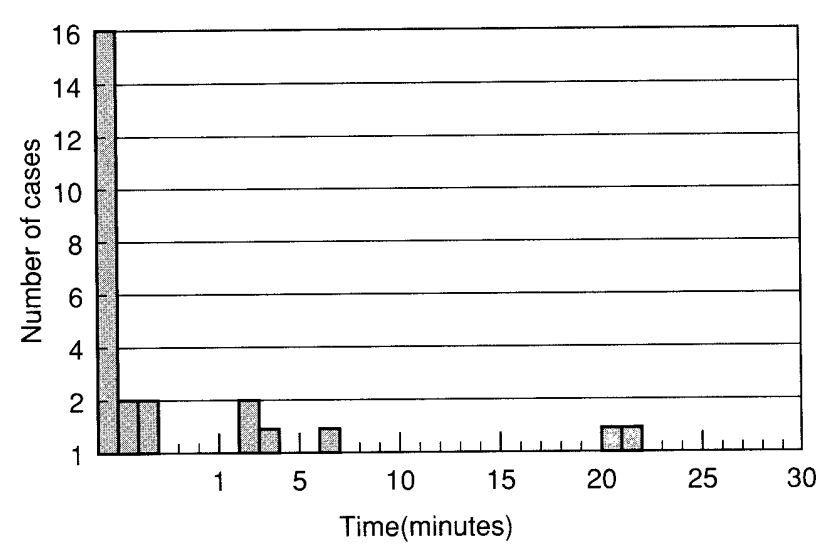

Fig. 1 Intolerant cases and its occlusion time Occlusion time of positive cases before new neurologic deficit developed. Sixteen of 26 cases had deficits appearing within 10 seconds at normotension. Two patients had deficits after induced hypotension.

\section{結 果}

BTO を予定した 121 血管中 120 血管で閉塞試験を施 行できたが，1血管で合併症のためテストを行うことが できなかった（症例 1)。テスト陰性は 94 血管，テスト 陽性が 26 血管であった. 陽性例のうち 24 例では閉塞開 始数秒〜 7 分以内に神経学的症状が出現したが, 閉塞開 始 10 秒以内に神経学的症状が出現した例が多く, ほと んどが 1 分以内であった。残る 2 例では, 閉塞から 20 分後のニカルジピンによる低血圧負荷直後に片麻痺, 意 識障害を生じ陽性と判断された（Fig. 1)。陽性例では, 診断造影における頸動脈の用手圧迫下の頸動脈造影で, ウィリス動脈輪を介する側副血行が乏しい傾向が認めら れたが, 造影の所見から予想されるテスト結果を示さな い例もみられた。

合併症は 5 例 $(4.2 \%)$ で認められた。症候性の合併症 を呈したのは 2 例 $(1.7 \%)$ であった。うち 1 例（症例 1）は，左半球の広範囲の脳梗塞をきたしたもので，1例 （症例 2）は一過性の神経脱落症状を認めた例である. 無 症候性の合併症を認めたものは 3 例 (2.5\%) であった。 1 例は, バルーンカテーテルをシースより挿入し大動脈 内を上行させていく際に腹部大動脈を損傷 (無症候性血 管解離)したため当日の閉塞テストを行うことができず, 2 週間後に施行した. 2 例でバルーンを拡張させた部位 に一致して内頸動脈の無症候性血管攣縮を認めたが, 同 部の血管解離や急性閉塞はきたさなかった.今回のテス トによる死亡例は認めなかった。

また, BTO を施行した後に, 当該血管の永久閉塞を施 行したものは 12 例であり, うち 3 例で虚血性合併症を 

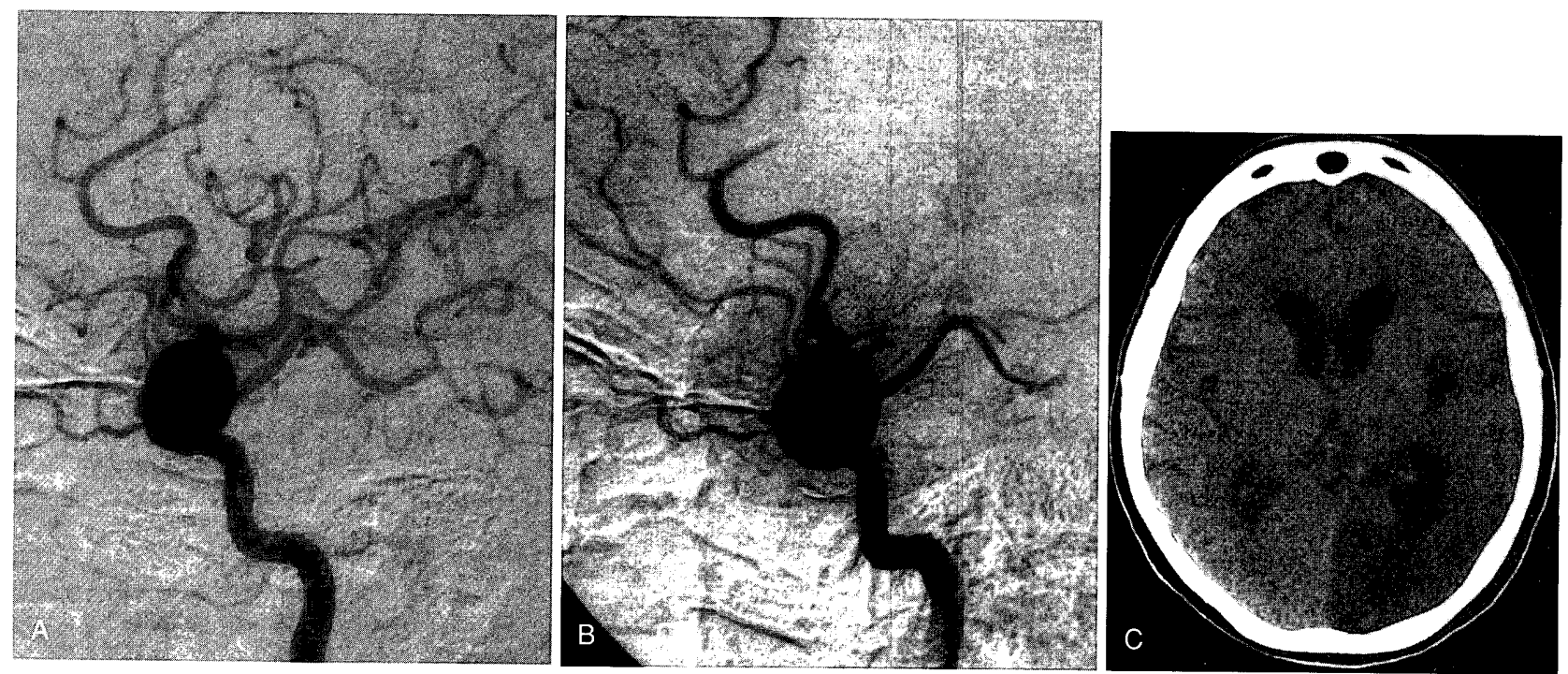

Fig. 2 Left internal carotid (IC)-ophthalmic aneurysm : 64-year-old woman

A : Left internal carotid angiogram shows large aneurysm.

B : Angiogram after patient became unconscious and right hemiparesis shows occlusion of anterior cerebral artery (ACA), middle cerebral artery (MCA), and posterior cerebral artery (PCA).

$\mathrm{C}:$ Final plain CT scan shows massive infarction of left hemisphere.

認めた。内訳は症候性脳梗塞，術後 CT で発見された無 症候性脳梗塞，一過性の名称失語がそれぞれ 1 例で，こ れら 3 例はいずれも BTO 陰性例であったが，バルーン 閉塞下での SPECT で閉塞側の血流低下を示していた。

\section{症例呈示}

【症例 1】64 歳, 女性

視力・視野障害の精査で左内頸動脈眼動脈部分岐部動 脈瘤を認め（Fig. 2A），手術目的で当科紹介となった。 手術に先立ち BTO が予定された. 診断造影の後,バルー ンカテーテルの挿入を試みたが，大動脈弓から左内頸動 脈へかけての屈曲蛇行が高度で，カテーテルを送り込む のに苦労し時間を要した。ようやくバルーンカテーテル を左内頸動脈に留置した直後に，意識障害，右片麻痺を 生じ，患側の前大脳動脈，中大脳動脈，後大脳動脈の閉 塞を認めた（Fig. 2B）。血栓溶解術を行ったものの，左 大脳半球に広範な梗塞巣を生じ（Fig. 2C), 右片麻痺, 運動性優位の失語が残存した。その後りハビリテーショ ンを行っていたが，約 8 力月後に未治療の動脈瘤の破裂 と考えられるクモ膜下出血をきたし死亡した。

【症例 2】 61 歳, 女性

健忘を自覚して来院．精查にて左内頸動脈上下垂体動 脈分岐部動脈瘤を認めた（Fig. 3A,B）。手術に先立ち BTO が行われた。バルーン閉塞後約 10 秒で右片麻㾝, 意識レベルの低下を生じたため直ちにバルーンを解除し
た。神経脱落症状は数分間かかって回復した。この時点 で確認の造影を行ったところ, 中大脳動脈 (M2) の 1 本 の閉塞を認めた (Fig. 3C). 塞栓性合併症と判断し血栓 溶解術を試みたが，再開通は得られなかった。閉塞部よ り末梢部の側副血行は良好で, 神経症状も完全に回復し ていたことから手技を終了した，その後新たな症状が出 現することなく, MRI 上も梗塞巣の出現は認められな かった (Fig. 3D)。検査 1 週後に予定通り開頭術が行わ れたが,結果的に動脈溜は extra-dural に存在しクリッピ ング術を行うことなく閉頭した。手術による合併症はな く，元気に退院した。

\section{考 察}

内頸動脈の一時遮断および永久閉塞を行うに際して問 題となるのは遮断中, 遮断後の脳虚血であり, 手術に先 立つ BTO は不可欠といえるが, 本検査の合併症等に関 する報告は少ない ${ }^{10)}$. 今回のシリーズでは 119 例に対す る BTOのうち 5 例 $(4.2 \%)$ に合併症が生じた。うち 2 例 $(1.7 \%)$ が症候性であり，3 例 (2.5\%) が無症候性で あった，症候性のうち，1例 $(0.8 \%)$ が恒久的合併症で あり，バルーンカテーテルを内頸動脈に挿入する際に意 識障害，片麻痺を生じ，広範な脳梗塞をきたした。この 例ではバルーンカテーテル挿入直後に症状が生じてお り，カテーテル操作に伴う合併症と考えられた。動脈硬 化による大動脈弓から左内頸動脈にかけての屈曲蛇行が 

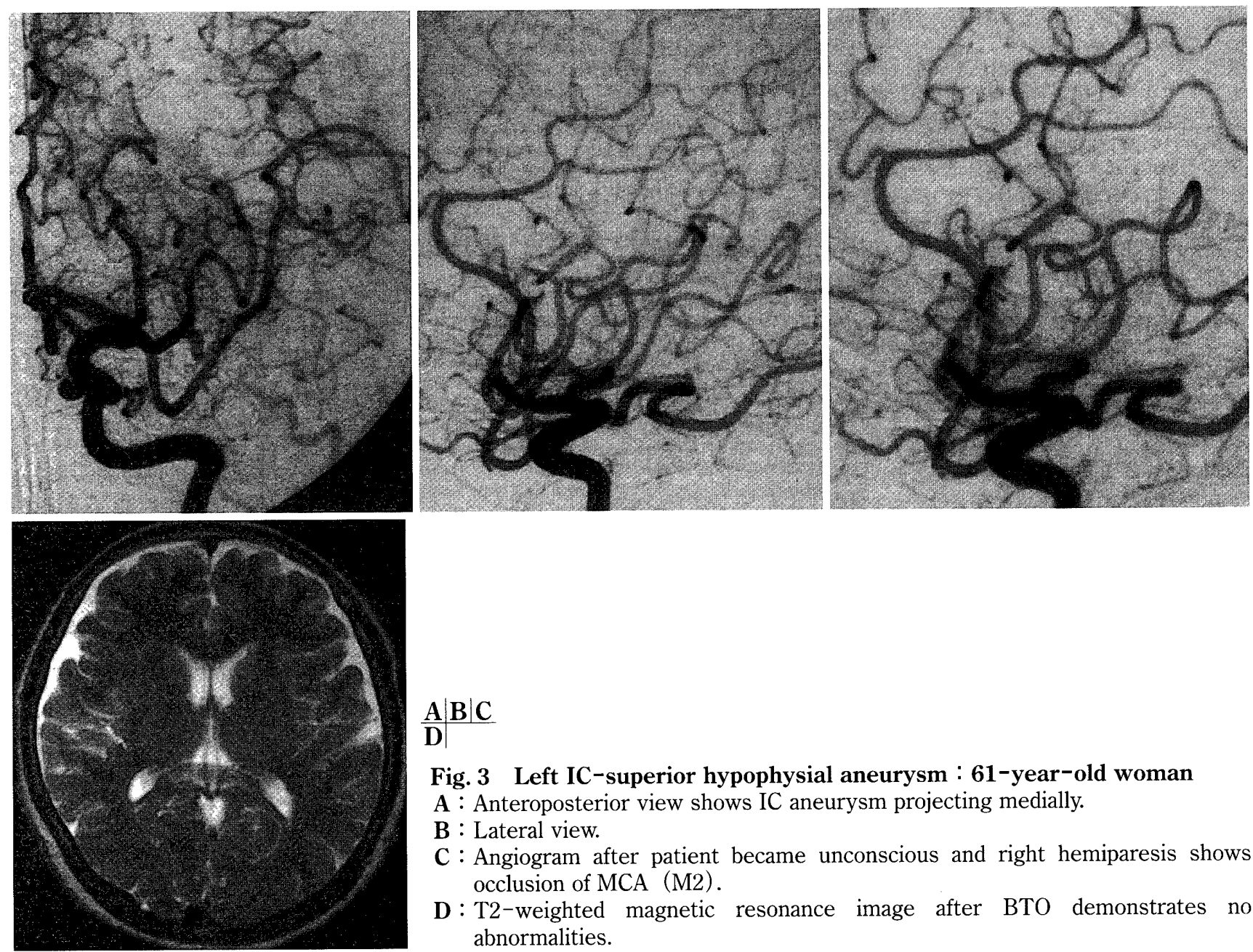

$\mathbf{A}|\mathbf{B}| \mathbf{C}$

D

Fig. 3 Left IC-superior hypophysial aneurysm : 61-year-old woman

A : Anteroposterior view shows IC aneurysm projecting medially.

B : Lateral view.

C : Angiogram after patient became unconscious and right hemiparesis shows occlusion of MCA (M2).

D : T2-weighted magnetic resonance image after BTO demonstrates no abnormalities.

高度で, カテーテル挿入に際して非常に苦労し, カテー テルが左内頸動脈起始部付近に挿入されたときに血管解 離を起こしたものと考えている。 バルーンカテーテルは 構造上, 通常使用している診断カテーテルよりも, 操作 性が悪く注意が必要である。また先端にバルーンがある ため，蒸気による先端形状変更に制限がある。この問題 はカテーテルの特性上仕方がないが，今後の改良が望ま れる。われわれは挿入困難例では無理にバルーンカテー テルを直接挿入することに固執せず，エクスチェンジテ クニックを採用するよう心がけている.

他の 1 例はバルーンによる閉塞開始 10 秒後に一過性 の意識障害・片麻痺をきたしすぐにバルーンを解除した が, 数分間神経症状 (片麻痺) が遷延した。通常は BTO で出現した神経症状は直ちに血流を再開すれば速やかに 回復するため, 確認の造影を行ったところ塞栓性の合併 症を認めた。この例では結果的に血栓溶解療法にても再 開通は得られなかったが, 幸いにも神経症状はその時点 で回復しており事なきを得た。塞栓性合併症により神経
症状が出たのか, 内頸動脈閉塞に耐性がないために神経 症状が出現し, 塞栓性合併症が加わったことで神経症状 の回復が通常の BTO の場合より遷延したのかは定かで はないが，本例では意識障害をきたしており単純な M2 閉塞では意識障害まで呈することは少なく, 後者が原因 ではないかと考えている。 また, カルテの記載から本例 では全身へパリン化が不十分 (ACT が 2 倍弱) だった可 能性が高く, その後は ACT を 3 倍近くに保つよう心が けている.

Mathis $ら^{10)}$ は 500 例の内頸動脈 BTO を検討し, 症候 性合併症を 8 例 $(1.6 \%)$ に認め, テスト開始後早期に出 現したものが多かったと報告しており，他の過去の報告 では, 症候性合併症の出現率は $0 \sim 8.3 \%{ }^{115) 6) 10) \sim 14)}$ で あった。これらをまとめると，全 681 例中 12 例 (1.8\%) となり, 今回のわれわれのシリーズでの $1.7 \%$ とぼ同 様の結果である.

BTO 陽性例となった例の神経症状出現までの時間は, 本シリーズでは開始直後に多くみられ, ほとんどが 1 分 
以内であった。過去の報告でも BTO の脳虚血症状はか なり早期に出現することが多いと報告されており 調査でも同様の傾向がみられた，また，本シリーズの症 候性合併症出現時期は 2 例とも BTO 施行の直前および 閉塞開始直後と早期であったことは注意を要する。

Dion $ら^{2)}$ は, 1,002 例の脳血管造影に関し検討し, $1.3 \%$ の症候性合併症を生じたと報告しており, Ernest ら゙3 は, 1,517 例の脳血管造影のうち $2.6 \%$ に症候性合併症を認 めたと報告している。これらと比較しても, 今回の症候 性合併症はほぼ同程度であり, BTO は術前検査として比 較的安全に行うことが可能と考えられる，無症候性合併 症に関し検討した報告は少ないが, Mathis ら ${ }^{10)}$ は, 内頸 動脈の BTO を施行した 500 例中 8 例 $(1.6 \%)$ に無症候 性合併症が生じたと報告している。わ执れの結果は 3 例 $(2.5 \%)$ でありほぼ同様であった。この 3 例は腹部大 動脈の血管解離とバルーン拡張部の血管攣縮 2 例で, と もに慎重なカテーテルおよびバルーン操作でかなり軽減 できるものと考えられた。

内頸動脈の一時遮断および永久閉塞に際しての脳虚血 の評価に関しては, BTO 時の低血圧負荷がその精度をさ

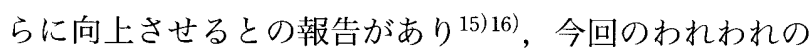
シリーズでも 2 例が低血圧負荷後にテスト陽性となっ た. BTOの精度を上げる意味でも試みるべき負荷だと考 えている.

BTO 中の脳機能, 脳血流の指標としては, 臨床症状に 加え, EEG, SEP, stump pressure, transcranial Doppler, stable xenon $\mathrm{CT}^{4)} \mathrm{SPECT}^{4) 9)}$ を用いた脳血流測定など が挙げられる。当然のことながら，側副血行路の状態を 把握することは非常に重要なことであるが，今回の脳血 管撮影上で cross filling が豊富であった例はテスト結果 が陰性となった例が多かったものの, cross filling が豊富 であると予想されたにもかかわらず，テスト陽性となつ た例も認められた. Jawad ら ${ }^{7}$ は脳血管造影上の cross filling の状態のみからは tolerable かどうかの判断は困難で あり，脳血流測定を併せて行わなければならないと報告 している. 脳血流の評価について Linskey $ら^{8)}$ は, 15 分 間の BTO を行い, その間の xenon CT 所見から脱落症状 を示すものを high-risk, 脱落症状はないが, cerebral blood flow (CBF) が $30 \mathrm{ml} / 100 \mathrm{~g} / \mathrm{min}$ 以下に低下するも のを moderate-risk, $\mathrm{CBF}$ が $30 \mathrm{ml} / 100 \mathrm{~g} / \mathrm{min}$ 以上のもの を low-risk, と 3 段階に分けている. Mathis ら ${ }^{10)}$ は, moderate-risk のうち，56\%が術後に神経脱落症状を呈した と報告している。 また, Anon ら ${ }^{1)}$ は, BTO 中 CBF が $25 \%$ 以上低下するものは脱落症状がなくても intolerance と 判断すべきとしている.
今回のわれわれのシリーズでは, BTO 後に親動脈の永 久的閉塞を施行した例は 12 例であった。うち 3 例で虚 血性合併症を認めた。これら 3 例はいずれも閉塞テスト 陰性であったが, balloon 閉塞下での SPECT で閉塞側の 血流低下を示していた。術中クリッピングに難渋し, 最 終的に内頸動脈の ligation $\varepsilon$, 浅側頭動脈-中大脳動脈吻 合術を行った 1 例では, 術後に術側の中大脳動脈領域の 㕕範な脳梗塞を生じた。海綿静脈洞部右内頸動脈瘤に対 し内頸動脈の ligation と high flow bypass を施行した 1 例 では，無症候性の右視床梗塞を生じた。残る 1 例は海綿 静脈洞部右内頸動脈瘤に対し IC ligation と浅側頭動脈中大脳動脈吻合術を行った例で, 術後一過性の名称失語 をきたした. 永久閉塞に対して tolerable かどうかの評価 は BTOの際の臨床症状のみからでは完全には判断でき ず, 指標を適宜組み合わせて総合的な評価をし, 手術時 の temporary occlusion の選択や, bypass 手術の必要性に ついて判断することが重要である.

\section{結 語}

内頸動脈における BTO は術前検査として重要である が,われわれの 119 例中 2 例 $(1.7 \%)$ に症候性合併症を きたした，過去の報告からも1〜2\%の恒久的合併症が起 こり得るため, 熟練した術者のもとで慎重に施行さ扎る べきである.

\section{文 献}

1) Añon VV, Aymard A, Gobin YP, Casasco A, Rüffenacht D, Khayata MH, Abizanda E, Redondo A, Merland JJ: Balloon occlusion of the internal carotid artery in 40 cases of giant intracavernous aneurysm: Technical aspects, cerebral monitoring, and results. Neuroradiology 34:245-251, 1992.

2) Dion JE, Gates PC, Fox AJ, Barnett HJ, Blom RJ: Clinical events following neuroangiography: A prospective study. Stroke 18: 997-1004, 1987.

3) Earnest F, Forbes G, Sandok BA, Piepgras DG, Faust RJ, Ilstrup DM, Arndt LJ : Complications of cerebral angiography : Prospective assessment of risk. AJR Am J Roentgenol $142: 247-253,1984$.

4) Eckard DA, Purdy PD, Bonte FJ : Temporary balloon occlusion of the carotid artery combined with brain blood flow imaging as a test to predict tolerance prior to permanent carotid sacrifice. AJNR Am J Neuroradiol 13: 1565-1569, 1992.

5) Fox AJ, Viñuela F, Pelz DM, Peerless SJ, Ferguson GG, Drake CG, Debrun G: Use of detachable balloons for proximal artery occlusion in the treatment of unclippable cerebral aneurysms. J Neurosurg 66: 40-46, 1987.

6) Gonzalez CF, Moret J: Balloon occlusion of the carotid artery prior to surgery for neck tumors. AJNR Am J Neuro- 
radiol 11:649-652, 1990

7) Jawad K, Miller D, Wyper DJ, Rowan JO : Measurement of $\mathrm{CBF}$ and carotid artery pressure compared with cerebral angiography in assessing collateral blood supply after carotid ligation. J Neurosurg $\quad$ 46: 185-196, 1977.

8) Linskey ME, Sekhar LN, Horton JA, Hirsch WL, Yonas H: Aneurysms of the intracavernous carotid artery: A multidisciplinary approach to treatment. J Neurosurg $75: 525-$ 534, 1991.

9) Mathews D, Walker BS, Purdy PD, Batjer H, Allen BC, Eckard DA, Devous MD, Bonte FJ: Brain blood flow SPECT in temporary balloon occlusion of carotid and intracerebral arteries. J Nucl Med 34: 1239-1243, 1993.

10) Mathis JM, Barr JD, Jungreis CA, Yonas H, Sekhar LN, Vincent D, Pentheny SL, Horton JA: Temporary balloon test occlusion of the internal carotid artery: Experience in 500 cases. AJNR Am J Neuroradiol 16:749-754, 1995.

11) Monsein LH, Jeffery PJ, VanHeerden BB, Szabo Z, Schwartz JR, Camargo EE, Chazaly J: Assessing adequacy of collateral circulation during balloon test occlusion of the internal carotid artery with ${ }^{99 \mathrm{~m}} \mathrm{Tc}-\mathrm{HMPAO}$ SPECT. AJNR
Am J Neuroradiol 12: 1045-1051, 1991.

12) Moody EB, Dawson RC, Sandler MD: ${ }^{99 \mathrm{M}} \mathrm{Tc}-\mathrm{HMPAO}$ SPECT imaging in interventional neuroradiology: Validation of balloon test occlusion. AJNR Am J Neuroradiol 12: 1043-1044, 1991.

13) Peterman SB, Taylor A, Hoffman JC: Improved detection of cerebral hypoperfusion with internal carotid balloon test occlusion and ${ }^{99 \mathrm{~m}} \mathrm{Tc}-\mathrm{HMPAO}$ cerebral perfusion SPECT imaging. AJNR Am J Neuroradiol 12 : 1035-1041, 1991.

14) Simonson TM, Ryals TJ, Yuh WTC, Farrar GP, Rezai K, Hoffman HT: MR imaging and HMPAO scintigraphy in conjunction with balloon test occlusion: Value in predicting sequelae after permanent carotid occlusion. AJR Am J Roentgenol 159: 1063-1068, 1992.

15) Standard SC, Ahuja A, Guterman LR, Chavis TD, Gibbons KJ, Barth AP, Hopkins LN : Balloon test occlusion of the internal carotid artery with hypotensive challenge. AJNR Am J Neuroradiol 16:1453-1458, 1995 .

16）滝 和郎，田中正人，永田 泉，中原一郎，菊地晴彦： 内頸動脈海綿静脈洞部動脈溜の治療一治療適応と治療方 針。脳外誌 5:180-187, 1996.

内頸動脈閉塞試験の合併症

$$
-119 \text { 例の経験から- }
$$

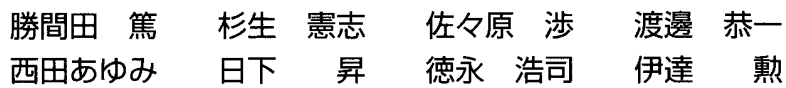

過去 12 年間の内頸動眽に対する balloon test occlusion（BTO）の，特に合併症につき検討した. 118 例 120 血管に対して BTO を施行し，テスト陰性 94 血管，陽性 26 血管であった．陽性例では閉 塞開始後 10 秒以内に神経症状が出現した例が多く，ほとんどが 1 分以内であった，症候性合併症を 2 例 (1.7\%) で認め, 1 例はバルーンカテーテル留置の際に内頸動脈に血管解離を起こし広範な脳梗 塞をきたしたもの，他の 1 例はバルーン解除直後に中大脳動脈 M2 部に脳塞栓を認めたもので，神経 症状は一過性で数分間で回復した。無症候性合併症として腹部大動脈の血管解離 1 例, バルーン拡張 部に一致した内頸動脈血管攣縮 2 例を認めた. BTO は比較的安全に行われる検査であるが, 過去の報 告からも 1〜2\%の恒久的合併症が起こり得るため, 熟練した術者のもとで慎重に施行されるべきであ る.

脳外誌 $13: 572-577,2004$ 